\title{
ANALISIS PERBANDINGAN PEMBERIAN KREDIT PEMILIKAN RUMAH (KPR) PADA BANK KONVENSIONAL DENGAN PEMBIAYAAN MURABAHAH (KPR) PADA BANK SYARIAH (Studi Kasus Pada Bank BJB dengan Bank BJB Syariah)
}

\author{
Muhammad Rizal Satria', Tia Setiani² \\ Politeknik Pos Indonesia \\ rizalstr@gmail.com ${ }^{1}$, yaa_oct25@yahoo.com ${ }^{2}$,
}

\begin{abstract}
Abstrak : Penelitian ini mencoba membandingkan sistem pembiayaan kredit perumahan antara Bank umum dan bank syariah. Tujuan dari perbandingan ini adalah untuk mengetahui Perbedaan sistem pembiayaan kredit perumahan oleh Bank Jabar Banten (BJB) dan Bank Jabar Syariah sebagai sampel. Banyak yang mengetahui bahwa bank konvensional menggunakan Suku bunga yang digunakan sebagai bunga dan bank syariah tidak menggunakannya. Analisis ini membandingkan kondisi yang berlaku, proses kredit perumahan diterapkan, akad atau initial Persyaratan, perhitungan angsuran, dan perawatan pelanggan yang terlambat masuk Membayar atau membayar sebelum waktunya. Berdasarkan analisis yang telah dilakukan, maka dapat disimpulkan bahwa Perbandingan pemberian kredit pada Bank Konvensional BJB dengan pembiayaan murabahah pada Bank BJB Syariah memiliki banyak persamaan dalam prosedur dan berkas persyaratan. Hanya saja pada aspek akad/perjanjian mempunyai perbedaan. Pada bank konvensional sepenuhnya menggunakan sistem bunga. Sedangkan pada bank syariah menerapkan akad murabahah dengan sistem bagi hasil dari keuntungan jasa dan transaksi riil.
\end{abstract}

Kata kunci: akad; Bank Konvensional; Sistem pembiayaan; Kredit perumahan; bunga; syariah

Abstract : This research tries to compare financing system of housing credit amongs to common bank and sharia bank. The purpose of this comparation is to know the differences of financing system of housing credit by Bank Jabar Banten (BJB) and Bank Jabar Syariah which used to be sample. People only know if common bank used interest as rates in return and sharia bank did not use it. The factors will be compared are conditions apply, proccess of housing credit applied, akad or initial requirements, calculation of installments, and treatment of customers who late on paying or paying before the time. Based on the analysis that has been done, it can be concluded that Comparison of credit provision in Conventional Bank BJB with murabahah financing at Bank BJB Syariah have many equations in procedure and requirement file. It's just that on the aspect of the contract / agreement has a difference. In conventional banks fully use the system of interest. While in syariah bank apply murabahah contract with profit sharing system from service advantage and real transaction.

Keywords: akad; common bank; financing system; housing credit; interest; sharia.

\section{PENDAHULUAN}

Salah satu kegiatan yang dilakukan bank adalah memberikan atau menolak kredit yang diajukan oleh nasabah.
Meskipun bank tergolong giat dalam mempromosikan penawaran dan mengumpulkan perkreditan, namun bank menjalankan tugas pasif dalam usaha 
perkreditan. Dilihat dari sektor usaha, kredit dibagi antara lain sektor industri, sektor perdagangan, sektor pertanian, peternakan dan perkebunan, sektor jasa serta sektor perumahan.

Dengan bertambahnya kepadatan penduduk maka pembangunan pemukiman semakin pesat, harga rumah menjadi mahal. Maka, bank menggunakan kesempatan ini dengan memanfaatkan Kredit Pemilikan Rumah (KPR) agar masyarakat dapat memiliki rumah secara mudah, apalagi dengan maraknya bank syariah, kini perbankan mempunyai dua opsi untuk Kredit Pemilikan Rumah (KPR), yaitu KPR syariah dari bank syariah yang dikenal dengan istilah Pembiayaan Pemilikan Rumah (PPR) dan KPR konvensional dari bank lainnya. Salah satu bank yang memiliki produk KPR adalah Bank Jabar Banten (BJB) sebagai bank konvensional dan Bank Jabar Banten Syariah.

Pembiayaan KPR pada kedua bank tersebut memiliki beberapa perbedaan, salah satunya perbedaanper hitungan angsuran. Pada bank BJB sebagai bank konvensional menggunakan prinsip bunga baik bunga flat maupun bunga efektif. Bunga flat adalah sistem perhitungan suku bunga yang besarannya mengacu pada pokok hutang awal. Penggunaan sistem bunga flat ini menyebabkan porsi bunga dan pokok dalam angsuran bulanan akan tetap sama. Bunga efektif merupakan kebalikan dari bunga flat, yaitu porsi bunga dihitung berdasarkan pokok hutang tersisa. Sehingga porsi bunga dan pokok dalam angsuran setiap bulan akan berbeda, meski besaran per bulannya tetap sama. Sistem bunga efektif ini biasanya diterapkan dalam pembiayaan jangka panjang seperti investasi maupun KPR.

Sementara untuk penerapan pembiayaan kepemilikan rumah di bank syariah tidak menggunakan bunga melainkan akad. Ada berbagai jenis akad, seperti akad jual-beli (Murabahah), jualbeli dengan pesanan khusus (Istishna'), sewa-beli (Ijarah Muntahiyah Bittamlik), dan penyertaan-sewa (Musyarakah Muntanaqisah). Pada Bank BJB Syariah menggunakan akad jual beli (Murabahah) dan sewa-beli (Ijarah Muntahiyah Bittamlik). Pada akad Murabahah (jualbeli) dan Ijarah Muntahiyah Bittamlik (IMBT/sewa-beli) khususnya, tentu memiliki tata cara dan keunikan masingmasing dalam pembiayaan kepemilikan rumah.

Pembiayaan kepemilikan rumah umumnya menggunakan akad Murabahah (jual-beli). Akad Murabahah (jual-beli) yaitu akad jual beli barang, dalam hal ini adalah rumah, dimana penjual menyatakan harga perolehannya dan marjin yang 
diinginkan pada saat penjualan kepada pembeli atas kesepakatan bersama. Akad yang lainnya adalah pembiayaan kepemilikan rumah dengan akad Ijarah Muntahiyah Bittamlik (IMBT) yang pada nyatanya masih jarang digunakan, merupakan pembiayaan yang menggunakan akad sewa-beli dimana nasabah menyewa barang atau dalam hal ini rumah yang pada akhir masa sewanya akan terjadi pengalihan hak kepemilikan rumah. Perpindahan kepemilikan atas rumah dengan akad ini dapat dilaksanakan dengan beberapa cara yaitu dengan hibah atau jual-beli.

Semakin ketatnya persaingan antara bank konvensional dengan bank syariah dalam menawarkan produk KPR masing-masing, mengharuskan para nasabah teliti dan pintar. Dari latar belakang yang telah disebutkan di atas, penulis tertarik untuk mengetahui: "Bagaimana perbandingan sistem pembiayaan KPR pada bank konvensional, dalam hal ini adalah Bank BJB, dengan pembiayaan KPR pada bank syariah, dalam hal ini adalah Bank BJB Syariah?”

\section{Tinjauan Pustaka}

\section{Bank}

Pengertian bank secara sederhana dapat diartikan sebagai lembaga keuangan yang kegiatan utamanya adalah menghimpun dana dari masyarakat dan menyalurkan kembali dana tersebut ke masyarakat serta memberikan jasa bank lainnya. Menurut Undang-Undang RI nomor 10 tahun 1998 tanggal 10 November 1998 tentang perbankan, pengertian bank adalah badan usaha yang menghimpun dana dari masyarakat dalam bentuk simpanan dan menyalurkannya kepada masyarakat dalam bentuk kredit atau bentuk-bentuk lainnya dalam rangka meningkatkan taraf hidup rakyat banyak (Kasmir, 2003).

\section{Bank Konvensional}

Bank konvensional adalah badan usaha yang menghimpun dana dari masyarakat dalam bentuk simpanan dan menyalurkannya kepada masyarakat dalam bentuk kredit atau bentuk-bentuk lainnya dalam rangka meningkatkan taraf hidup rakyat banyak (UU RI No. 10 Tahun 1998 dalam Kasmir). Dalam operasional bank konvensional, sebagian besar ditentukan oleh kemampuannya dalam menghimpun dana masyarakat melalui pelayanan dan bunga yang menarik.

\section{Bank Syariah}

Bank syariah adalah bank yang melaksanakan kegiatan usaha berdasarkan prinsip syariah, termasuk unit usaha syariah dan kantor cabang bank asing yang melakukan kegiatan berdasarkan prinsip 
syariah yang dalam kegiatannya memberikan jasa dalam lalu lintas pembayaran (UU RI No. 10 Tahun 1998 dalam Kasmir). Menurut Kasmir , menyebutkan bahwa bank syariah adalah bank yang tata cara beroperasinya didasarkan kepada tata cara bermualat secara islam, artinya bank syariah mengacu kepada ketentuan-ketentuan AlQuran dan Al-Hadist. Bank syariah ialah bank yang berasaskan 5, yaitu: kemitraan, keadilan, transparansi, dan universal serta melakukan kegiatan usaha perbankan berdasarkan prinsip syariah.

\section{Kredit}

Kata kredit berasal dari bahasa Romawi "credere" yang artinya percaya. Sedangkan kredit menurut UUP 1967 pasal 1c adalah penyediaan uang atau tagihantagihan berdasarkan persetujuan pinjam meminjam antara bank dengan pihak lain dalam hal mana pihak meminjam berkewajiban melunasi utangnya setelah jangka waktu tertentu dengan jumlah bunga yang telah ditetapkan. Kredit memiliki dua unsur pihak, yaitu kreditur (Bank) dan debitur (Nasabah) yang melakukan hubungan kerja sama yang saling menguntungkan. Di dalam perkreditan terdapat unsur-unsur yang harus ada, yaitu: kepercayaan, persetujuan, penyerahan barang, jasa atau uang, jangka waktu, unsur resiko, dan unsur keuntungan (bunga). Pemberian kredit tanpa analisis terlebih dahulu akan menyebabkan kerugian pada pihak bank (Kasmir, 2003:101).

\section{Pembiayaan}

Di dalam perbankan syariah, istilah kredit tidak dikenal karena bank syariah memiliki skema yang berbeda dengan bank konvensional dalam menyalurkan dananya kepada pihak yang membutuhkan. Bank syariah menyalurkan dananya kepada nasabah dalam bentuk pembiayaan.

Menurut Undang-undang Perbankan nomor 10 tahun 1998 pengertian pembiayaan adalah penyediaan uang atau tagihan yang dapat dipersamakan dengan itu, berdasarkan persetujuan atau kesepakatan antara bank dengan pihak lain yang mewajibkan pihak yang dibiayai untuk mengembalikan uang atau tagihan tersebut setelah jangka waktu tertentu dengan imbalan atau bagi hasil.

\section{Pengertian KPR}

KPR atau Kredit Kepemilikan Rumah merupakan salah satu jenis pelayanan kredit yang diberikan oleh bank kepada para nasabah yang menginginkan pinjaman khusus untuk memenuhi kebutuhan dalam pembangunan rumah atau renovasi rumah. KPR sendiri muncul 
karena adanya kebutuhan memiliki rumah yang semakin lama semakin tinggi tanpa diimbangi daya beli yang memadai oleh masyarakat (Kasmir, 2008:25).

Seperti layaknya produk perbankan yang memiliki keanekaragaman jenis, KPR secara umum dibagi menjadi 2 jenis, yaitu:

1) KPR Subsidi adalahsuatu kredit yang diperuntukkan kepada masyarakat yang memiliki kemampuan ekonomi menengah ke bawah. Adapun bentuk dari subsidi ini telah diatur oleh pemerintah, sehingga tidak semua masyarakat dapat mengajukan kredit jenis ini. Secara umum batasan yang ditetapkan oleh pemerintah dalam memberikan subsidi adalah penghasilan pemohon dan maksimum kredit yang diberikan. 2)KPR non Subsidi adalahsuatu KPR yang diperuntukkan bagi seluruh masyarakat tanpa adanya campur tangan pemerintah. Ketentuan KPR ditetapkan oleh bank itu sendiri sehingga penentuan besarnya suku bungapada bank konvensional maupun margin pada bank syariah dilakukan sesuai dengan kebijakan bank yang bersangkutan.

\section{Bunga}

Bunga adalah tambahan yang dikenakan untuk transaksi pinjaman uang yang diperhitungkan dari pokok pinjaman tanpa mempertimbangkan manfaat atau hasil pokok tersebut berdasarkan jangka waktu dan diperhitungkan secara pasti dimuka berdasarkan prosentase. Bagi bank yang menjalankan operasionalnya secara konvensional dapat diartikan sebagai balas jasa yang diberikan oleh bank kepada nasabah yang membeli atau menjual produknya.

\section{Murabahah}

Murabahah adalah akad jual beli barang dengan menyatakan harga perolehan dan keuntungan (margin) yang disepakati oleh penjual dan pembeli. Pembayaran Murabahah dapat dilakukan secara tunai atau cicilan. Selain itu, dalam Murabahah juga diperkenankan adanya perbedaan dalam harga barang untuk cara pembayaran yang berbeda. Bank dapat memberikan potongan apabila nasabah mempercepat pembayaran cicilan atau melunasi piutang Murabahah sebelum jatuh tempo.

Harga yang disepakati dalam Murabahah ini adalah harga jual sedangkan harga beli harus diberitahukan. Potongan yang diperoleh bank dari pemasok merupakan hak nasabah. Apabila potongan itu terjadi setelah akad, maka pembagian potongan tersebut dilakukan berdasarkan perjanjiann yang dimuat dalam akad. Bank dapat meminta nasabah agunan atas piutang Murabahah, antara lain dalam bentuk barang yang telah dibeli dari bank. Bank 
dapat meminta kepada nasabah urban sebagai uang muka pembelian pada saat akad apabila kedua belah pihak bersepakat. Urban menjadi bagian pelunasan piutang Murabahah apabila Murabahah jadi dilaksanakan, tetapi apabila Murabahah batal, urban dikembalikan kepada nasabah setelah dikurangi dengan kerugian sesuai dengan kesepakatan. Ketika diketahui uang muka itu lebih kecil dari kerugian bank maka bank dapat meminta tambahan dari nasabah.

\section{Perbedaan Bank Konvensional Dengan Bank Syariah}

Dalam beberapa hal, bank konvensional dan bank syariah memiliki persamaan, terutama dalam sisi teknis penerimaan uang, mekanisme transfer, teknologi komputer yang digunakan, syarat-syarat umum memperoleh pembiayaan seperti KTP, NPWP, proposal, laporan keuangan dan sebagainya. Namun, terdapat banyak perbedaan mendasar diantara keduanya, antara lain:

\section{Tabel 1}

Perbedaan Bank Konvensional Dengan Bank Syariah

\begin{tabular}{|c|l|l|}
\hline No & \multicolumn{1}{|c|}{ Bank Syariah } & \multicolumn{1}{|c|}{ Bank Konvensional } \\
\hline 1 & Berinvestasi pada usaha yang halal & Bebas nilai \\
\hline 2 & Atas dasar bagi hasil margin keuntungan dan fee & Sistem bunga \\
\hline 3 & $\begin{array}{l}\text { Besaran bagi hasil berubah-ubah tergantung kinerja } \\
\text { usaha }\end{array}$ & Besarannya tetap \\
\hline 4 & Profit dan falah oriented & Profit oriented \\
\hline 5 & Pola hubungan kemitraan & Hubungan debitur-kreditur \\
\hline 6 & Ada Dewan Pengawas Syariah & Tidak ada lembaga sejenis \\
\hline
\end{tabular}

\section{Metode Penelitian}

\section{Jenis Penelitian}

Dalam penelitian ini menggunakan penelitian komparatif, menurut Sugiyono (2017:209) penelitian komparatif adalah "rumusan masalah yang memandu peneliti untuk membandingkan antara konteks sosial atau domain satu dibandingkan dengan yang lain".

\section{Metode Pengumpulan Data}

1. Wawancara (Interview) digunakan sebagai teknik pengumpulan data apabila peneliti ingin melakukan studi pendahuluan untuk menemukan permasalahan yang harus diteliti, tetapi juga apabila peneliti ingin mengetahui hal-hal dari responden yang mendalam. 
2. Studi kepustakaan (Library

Researc) merupakan metode pengumpulan kepustakaan yang dilakukan dengan cara mempelajari, meneliti dan menelaah buku-buku referensi, catatan kuliah dan bukubuku lain yang ada kaitannya dengan cakupan judul yang diambil.

\section{Hasil dan Pembahasan}

1. Analisis Sistem Pemberian KPR pada Bank BJB KCP Sarijadi

Alur kerja prosedur pemberian KPR pada Bank BJB KCP Sarijadi adalah sebagai berikut:

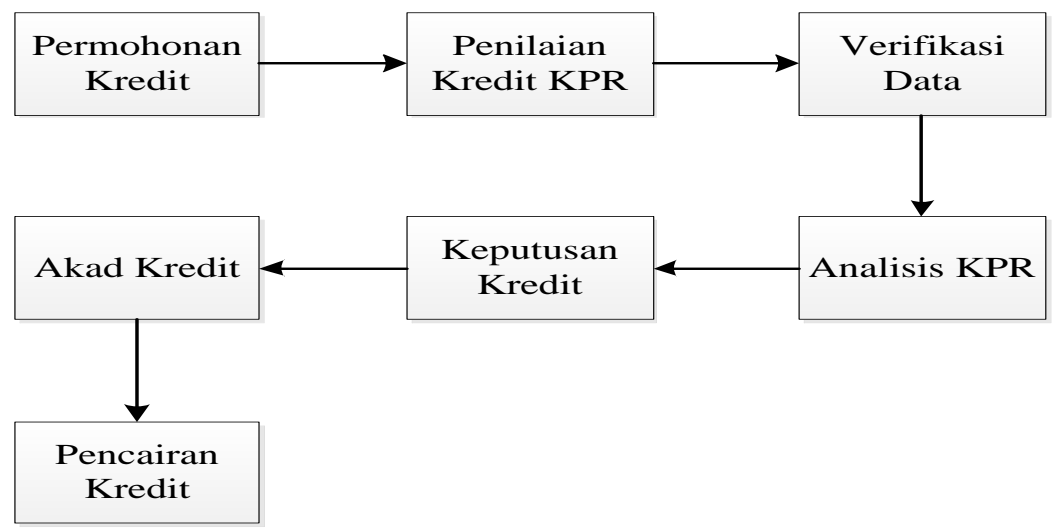

Sumber: Bank BJB KCP Sarijadi

\section{Gambar 1. Skema Pemberian Kredit di BJB KCP Sarijadi}

2. Analisis Pembiayaan Murabahah KPR pada Bank BJB Syariah KCP Cimahi

Bank BJB Syariah adalah bank yang menerapkan prinsip Syariah Islam dalam menjalankan operasionalnya. Pembiayaan Syariah adalah produk pembiayaan yang akan membantu nasabahnya untuk memiliki rumah (ready stock/bekas), apartemen, ruko, rukan, kios maupun pengalihan take-over KPR dari bank lain.

Langkah-langkah atau prosedur pembiayaan murabahah KPR dapat dilihat dalam skema berikut ini:

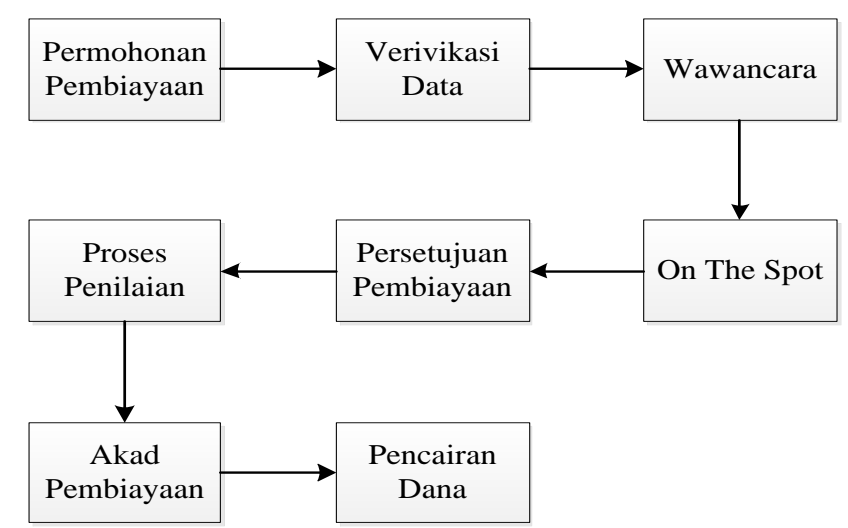

Sumber: Bank BJB KCP Cimahi 
Gambar 2. Langkah-langkah prosedur permohonan pembiayaan

3. Analisis Perbandingan Pemberian dengan Pembiayaan Murabahah Kredit Pemikan Rumah (KPR) (KPR) pada Bank BJB Syariah pada Bank BJB KCP Sarijadi KCP Cimahi

Tabel 2

Perbedaan Sistem Pemberian Kredit KPR dan Pembiayaan Murabahah KPR

\begin{tabular}{|l|l|l|}
\hline \multirow{2}{*}{ Keterangan } & Bank BJB KCP Sarijadi & $\begin{array}{l}\text { Bank BJB Syariah KCP } \\
\text { Cimahi }\end{array}$ \\
\hline \multirow{4}{*}{$\begin{array}{l}\text { Sistem Pemberian Kredit } \\
\text { KPR/Pembiayaan } \\
\text { Murabahah KPR }\end{array}$} & Permohonan kredit & Permohonan pembiayaan \\
\cline { 2 - 3 } & Penilaian Kredit KPR & Verifikasi Data \\
\cline { 2 - 3 } & Analisis KPR & Wawancara \\
\cline { 2 - 3 } & Keputusan kredit & On The Spot \\
\cline { 2 - 3 } & Akad kredit & Proses Penilaiain \\
\cline { 2 - 3 } & & Akad Pembiayaan \\
\cline { 2 - 3 } & Pencairan kredit & Pencairan Dana \\
\hline
\end{tabular}

Persamaan antara lain pada syarat administrasi dan syarat-syarat dalam membuka kredit antara kedua bank, baik bank konvensional maupun bank syariah ternyata tidak banyak berbeda. Hal lain yang dibandingkan adalah prosedur pemberian kredit antar bank konvensional dengan bank syariah yang tidak banyak berbeda.

Tabel 3

Perbedaan Pemberian Kredit KPR pada Bank Konvensional dengan Pembiayaan Murabahah KPR pada Bank Syariah

\begin{tabular}{|c|c|c|}
\hline $\begin{array}{l}\text { Kredit Pemilikan Rumah dan } \\
\text { Pembiayaan Murabahah KPR }\end{array}$ & Bank BJB KCP Sarijadi & $\begin{array}{l}\text { Bank BJB Syariah KCP } \\
\text { Cimahi }\end{array}$ \\
\hline Prinsip & Bunga & Bagi hasil \\
\hline Akad yang ditetapkan & Duniawi & $\begin{array}{l}\text { Duniawi dan } \\
\text { Ukhrawi }\end{array}$ \\
\hline Pelunasan sebelum jatuh tempo & Denda/pinalty $1 \%$ & Tidak ada denda/pinalty \\
\hline $\begin{array}{l}\text { Bidang usaha/barang yang } \\
\text { dibiayai }\end{array}$ & Tidak jelas halal dan haramnya & $\begin{array}{l}\text { Harus jelas halal dan } \\
\text { haramnya }\end{array}$ \\
\hline Telat membayar angsuran & Denda $1,5 \%$ & Infaq/shadaqoh \\
\hline Hubungan dengan nasabah & Debitur - kreditur & Kemitraan \\
\hline
\end{tabular}

Sumber: Bank BJB dan Bank BJB Syariah. (data diolah) 


\section{PEMBAHASAN}

Pada dasarnya sistem pemberian kredit KPR pada Bank BJB Konvensional dengan pembiayaan murabahah KPR pada Bank BJB Syariah memiliki banyak persamaan, yaitu dalam prosedur pengajuan sampai dengan pencairan dana. Kedua jenis bank penyalur KPR ini samasama mengharuskan Anda menyiapkan dokumen lengkap permohonan KPR. Beberapa syarat diantaranya fotokopi KTP pemohon, surat nikah (atau cerai bila sudah menikah dan bercerai), slip gaji, surat keterangan bekerja, fotokopi NPWP, rekening tabungan dan lain-lain. Dokumen yang tidak lengkap akan membuat permohonan Anda ditolak, baik oleh bank syariah ataupun bank konvensional.

Perbandingan sistem pemberian kredit KPR pada Bank BJB Konvensional dengan pembiayaan murabahah KPR pada Bank BJB Syariah terdapat pada akad/perjanjian. Pada Bank BJB Konvensional menggunakan sistem bunga. Pada sistem bunga, dalam perjanjian pihak bank berasumsi harus selalu untung tanpa mempertimbangkan untung atau rugi. Sedangkan pada Bank BJB Syariah menggunakan sistem bagi hasil, yaitu sistem yang meliputi cara pembagian hasil usaha antara bank dengan nasabah. Pada Bank Syariah kemungkinan untung atau rugi akan ditanggung bersama.

Dalam kredit KPR ini bank konvensional lebih diminati. Ini disebabkan karena bunga yang diberikan lebih rendah dengan menggunakan sistem bunga flat selama 2 tahun, dan tahun selanjutnya bunga yang dikenakan adalah bunga yang berlaku dipasar. Jadi pada saat bunga di pasar turun, maka cicilan nasabah lebih kecil.

\section{SIMPULAN}

Berdasarkan analisis yang telah dilakukan, maka dapat disimpulkan bahwa Perbandingan pemberian kredit pada Bank Konvensional BJB dengan pembiayaan murabahah pada Bank BJB Syariah memiliki banyak persamaan dalam prosedur dan berkas persyaratan. Hanya saja pada aspek akad/perjanjian mempunyai perbedaan. Pada bank konvensional sepenuhnya menggunakan sistem bunga. Sedangkan pada bank syariah menerapkan akad murabahah dengan sistem bagi hasil dari keuntungan jasa dan transaksi riil.

Berdasarkan hasil penelitian yang telah dilakukan, peneliti memberikan 
beberapa saran yang diharapkan dapat bermanfaat bagi Bank BJB KCP Sarijadi dan Bank BJB Syariah KCP Cimahi adalah sebagai berikut:

1. Dalam menjalankan prosedur pemberian kredit KPR lebih teliti agar tercapainya pelaksanaan analisis penilaian kredit secara optimal yang berupa analisis 5 of $\mathrm{C}$ dapat terpenuhi sehingga tidak ada kredit macet.

2. Dalam pembiayaan murabahah KPR sebaiknya pihak bank harus terus teliti dalam memeriksa syaratsyarat calon debitur dan pihak bank juga harus lebih teliti dalam melakukan analisis pembiayaan terhadap nasabah.

DAFTAR PUSTAKA

Chikmah, Achasih Nur. 2009. Analisis Pernbandingan Sistem Pemberian Kredit Bank Konvensional dengan Pembiayaan Bank Syariah pad Usaha Mikro, Kecil, dan Menengah. Jurnall: Universitas Negeri Surabaya. (Online), (http://ejournal.undip.ac.id/inde x.php/smo/article/download/134 05/10129.html, diakses 8 Juli 2017)
Dewi, Kadek Ayu Krisna, dkk. 2014. Pengaruh CAR, LDR, BOPO Terhadap ROA Pada Bank Umum dan Terdaftar di BEI tahun 2008-2012. Jurnal: Universitas Pendidikan Ganesha. (Online), (http://www.perbankan.ac.id/ojs /index.php/fe1/article/view/187, diakses 8 Juli 2017)

Djurna, Wenny. 2011. Analisis Perbandingan Metode Pemberian Kredit di Bank Konvensional dengan Pembiayaan Musyarakah di Bank Syariah. Jurnal: Universitas Putra Indonesia. (Online)

(ejournal.unpi.ac.id/index.php/s mo/article/download/13405/101 29, diakses 8 Juli 2017)

Hardjono,2008,MudahMemilikiRumahLew at KPR,Jakarta:PT.Pustaka Grahatama.

Kasmir. 2016. Manajemen Perbankan. Jakarta: PT Raja Grafindo Persada.

Kasmir. 2016. Pengantar Manajemen Keuangan. Jakarta: PT Raja Grafindo Persada.

Surya, Ari. 2011. Analisis Perbandingan Metode Pemberian Kredit pada Bank Konvensional dengan 
Muhammad Rizal Satria : Analisis Perbandingan Pemberian Kredit Pemilikan Rumah (Kpr) Pada Bank Konvensional Dengan Pembiayaan Murabahah (Kpr) Pada Bank Syariah

Pembiayaan Murabahah pada

Bank Syariah (Studi Kasus

PT.Bank Panin,Tbk dan PT

Bank Muamalat. Jurnal:

Universitas Siliwangi.(Online)

https://journal.unsil.ac.id/nju/ind

ex.php/jejak/article/download/3

882/3524, diakses 7 Juli 2017)

Mahmudah. 2011. Analisis Perbandingan

Sistem Permberian Kredit

Secara Konvensional dan

Syariah Pada PT.BNI (Persero)

Sentral Kredit Medan dan

PT.BNI Syariah Cabang Medan.

Skripsi: Universitas Sumatra

Utara.

(Online), (http://eprints.unsumut. ac.id/2350/1/HALAMAN\%20D

EPAN.pdfdiakses 8 Juli 2017)

Muthaher, Osmad. 2012. Akuntansi

Perbankan

Syariah.

Yogyakarta: Graha Ilmu.

Qudsiah, Nisa. 2016. Pengaruh Capital

Adequacy Ratio (CAR) dan

Loan To Deposit Ratio (LDR)

Terhadap Return On Assets

(ROA) Pada Bank Pemerintah

Yang Terdaftar di BEI Tahun

2011-2015. Tugas Akhir tidak

diterbitkan. Bandung: Politeknik

Pos Indonesia.

Sugiyono. 2013. Statistika Untuk

Penelitian. Bandung: Alfabeta.
Sugiyono. 2017. Metode Penelitian Kuantitatif, Kualitatif dan $R \& D$. Bandung: Alfabeta.

Undang-Undang No.10 Tahun 1998.

Tentang Bank dan Kredit.

(http://www.bankbjb.co.id. diakses 1

Agustus 2017). (Online)

(http://www.bjbsyariah.co.id. diakses 1

Agustus 2017). (Online) 